\title{
カルシウム・シリケート化合物の炭酸化反応*
}

\author{
浅野駿吉・釜谷幸典・井上嘉重
}

(神戸大学工学部)

\section{On the Carbonation of Calcium Silicate Compounds}

\author{
By \\ Shunkichi ASANO, Yukinori KAMATANI and Yoshiki INOUE \\ (Department of Industrial Chemistry, Faculty of Technology, Köbe University)
}

\begin{abstract}
The carbonation of calcium silicate compounds constituting hydrated cement was investigated individually. The samples of xonotlite, tobermorite (2 species), $C_{3} S$ and $\beta-C_{2} S$, synthesized from pure chemicals, were carbonated by $100 \% \mathrm{CO}_{2}$ gas at gas state (gas reaction), or at wet state of added $100 \%$ water (liquid reaction). Reaction rates and the fraction of calcite in $\mathrm{CaCO}_{3}$ were determined by $\mathrm{X}$-ray quantitative analysis. Species and degree of crystallinity of the carbonation products were examined by $\mathrm{X}$-ray diffraction method and infra-red absorption method.

The results obtained are as follows:

1) The carbonation of hydrated calcium silicates proceeds rapidly, the rate determining process is a surface reaction. The difference of reactivity between xonotlite produced in higher temperature and tobermorite in lower temperature, and in tobermorites of different crystallinity are observed. The reaction products are $\mathrm{CaCO}_{3}$ and silica gel, and $\mathrm{CaCO}_{3}$ is almost crystalline, the morphologic habit is calcite both in gas reaction and in liquid reaction.

2) The carbonation of anhydrous calcium silicates proceeds more slowly than that of the hydrated compounds, but more rapidly compared to that of anhydrous calcium aluminates The reactivity of $\beta-\mathrm{C}_{2} \mathrm{~S}$ is higher than that of $\mathrm{C}_{3} \mathrm{~S}$ in the carbonation, but the reverse is in the hydration. This fact is seen significant to resolve a reaction mechanism in the carbonation. The special feature of $\mathrm{CaCO}_{3}$ produced in the reaction of the anhydrous compounds is distinguished from that of the hydrated compounds, that is predominant of amorphous and different morphologic habit.
\end{abstract}

[Received January 11, 1971]

\section{1. 緒 言}

前報》で水酸化カルシウムの拻酸化反応について検討 した際，反応方法としてガス反応と液反忘を用いると， 両者では反态機構や生成物が相違することを明らかにし た。また簡易な固体反応速度式を提案し，これを実駼結

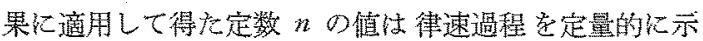
すこと孛のべた。この結諭は他の水和セメントト成分の炭 酸化反応にも適用されるので, 本研究に括いてもこれら の点を考慮して反応の解析を行なった。

本研究では水和它メントの構成成分のらち，代表的な カルシウム・シリケート水和物辞よび無水物を純薬合成 したものについて，個々に炭酸化反応を解明し，穴の反 応の特徴を明ら加にする。

カルシウム・シリケート化合物の生成条件, 構造, 性 質についての研究は，これまで数多くなされ総括もされ

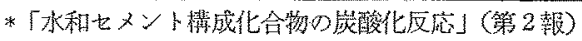

ている ${ }^{2), 3)}$ ，水和物はポルトランド・セメント中の水硬 性成分の $\mathrm{C}_{3} \mathrm{~S}$ 抒よび $\beta-\mathrm{C}_{2} \mathrm{~S}$ の水和, 混合七メント水 和時の水酸化力ルシウムと珪酸のポゾラン反応に上り生 成し，セメントの硬化機能に寄与している、水和物の種 類は普通の養生ではトベルモライト，高玨高温の養生で はゾノトライトが主要なもので多る。水和物の炭酸化は その物性汇種々の影響があるが，例兑淁强度は水和物の 種類によって増大または減少することが報告されてい $3^{4\rangle, 5)}$ ，乙かし水和物の反応の速さや生成物については 詳しく検討されていない。

無水物はポルトランド。セメントに重要な水硬性成分 として $\mathrm{C}_{3} \mathrm{~S}$ および 卜中にす末水和成分として存在する。これまでに水和セ メントの炭酸化において無水物の反忘が進む事実をの心゙

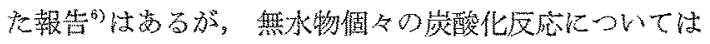
ほとんど知られていない。立た，無水物の水和掠よび炭 
Table 1. Conditions of synthesis and properties of hydrated calcium silicate samples.

\begin{tabular}{|c|c|c|c|c|c|c|c|}
\hline \multirow[b]{2}{*}{ Species } & \multirow{2}{*}{$\begin{array}{c}\text { Raw materials } \\
\mathrm{CaO} / \mathrm{SiO}_{2} \\
\text { (mole) }\end{array}$} & \multicolumn{3}{|c|}{ Hydrothermal synthesis } & \multicolumn{2}{|c|}{ Properties } & \multirow[b]{2}{*}{ References } \\
\hline & & $\begin{array}{l}\text { Press. } \\
\text { (atm) }\end{array}$ & $\begin{array}{c}\text { Temp. } \\
\left({ }^{\circ} \mathrm{C}\right)\end{array}$ & $\begin{array}{l}\text { Duration } \\
\text { (hr) }\end{array}$ & Shape $(\mathrm{m})$ & $\underset{(\mu)}{\text { Mean radius }}$ & \\
\hline Xonotlite & 1.0 & $40 \sim 50$ & $249 \sim 263$ & 45 & needle(2) & 0.1 & \\
\hline Tobermorite(1) & 1.5 & $4.0 \sim 4.5$ & $143 \sim 147$ & 48 & thin plate (1) & 0.1 & C-S-H(I) • \\
\hline Tobermorite (2) & 1.0 & $4.0 \sim 4.5$ & $143 \sim 147$ & 90 & thin plate(1) & 0.1 & $11 \AA$ tobermorite ${ }^{*}$ \\
\hline
\end{tabular}

- approximate from X-ray diffraction pattern

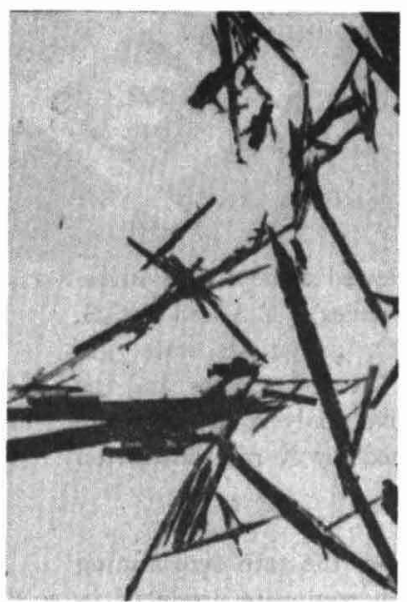

1) xonotlite $(\times 3,200)$

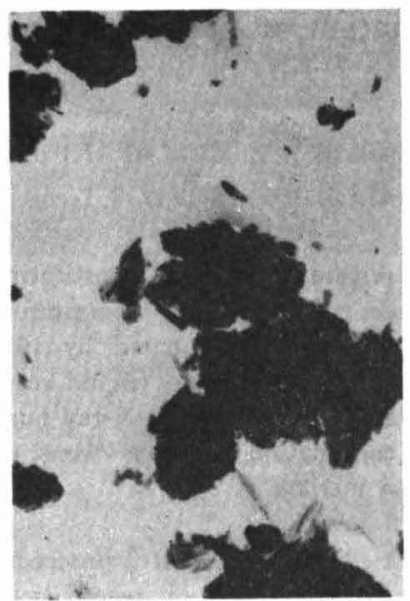

2) tobermorite $(1)(\times 8,000)$

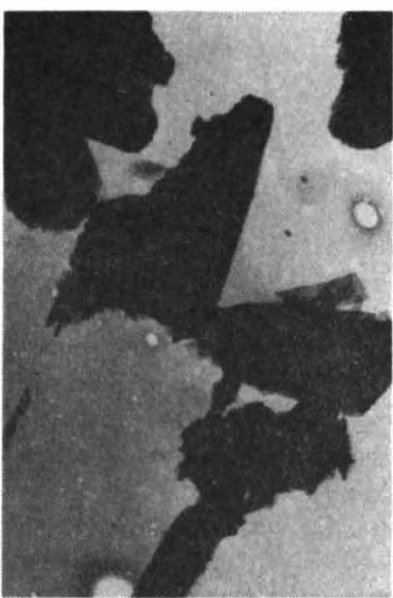

3) tobermorite $(2)(\times 2,800)$

Fig. 1. Electron micrograph of hydrated calcium silicate samples.

酸化における反応性の比較は, 炭酸化の反応機構の解明 につながり興味ある問題であるが，これまでこのような 検討もされていない. 本研究ではこれらの点を若干明ら かにしたのでここに報告する.

\section{2. 実 験 方 法}

\section{1 試料}

水和物のソ゚ノトライトおよびトベルモライト 2 種は水 酸化カルシウム (陚薬特級), シリカ・ゲル(試薬 1 級) および脱炭酸水を混合し，オートクレーブ中 で一定の飽和水蒸気圧下に水熱合成し，生成 物を乳鉢ですり潰し，風ふるい機により粒度 をそろえた，炭酸化実験に用いる試料は純度， 粒子の形状およぴ大きさをX線回折および電 子顥微鏡により確認してある. 各試料の合成 条件および性状を 表-1に, また電顥写真を 図-1 に示す.

無水物の $\mathrm{C}_{3} \mathrm{~S}$ および $\beta-\mathrm{C}_{2} \mathrm{~S}$ は純薬合成 したものを乳鈰ですり潰し，風子るい機にか けて粒度をそろえた。各試料の合成条件およ ひ性状を表-2に，また電䫓写真を図-2に 示寸.

\section{2 炭酸化反応}

前報でのベた炭酸化方法に準し，ガス反応 と液反応によった，反応装置は前報のものを
そのまま用いる. ガス反応は乾燥試料に $100 \% \mathrm{CO}_{2}$ ガ ス (湿度 80\%), 液反応は $100 \%$ 量の脱炭酸水を混し

Table 2. Conditions of synthesis and properties of anhydrous calcium silicate samples.

\begin{tabular}{|c|c|c|c|c|c|}
\hline \multirow[b]{2}{*}{ Species } & \multirow{2}{*}{$\begin{array}{l}\text { Raw } \\
\text { materials } \\
\mathrm{CaO} / \mathrm{SiO}_{2} \\
\text { (mole) }\end{array}$} & \multicolumn{2}{|c|}{ Synthesis } & \multicolumn{2}{|c|}{ Properties } \\
\hline & & $\begin{array}{l}\text { Temp. } \\
\left({ }^{\circ} \mathrm{C}\right)\end{array}$ & $\begin{array}{c}\text { Duration } \\
\text { (hr) }\end{array}$ & $\begin{array}{c}\text { Shape } \\
(\mathrm{m})\end{array}$ & $\begin{array}{l}\text { Mean } \\
\text { radius } \\
(\mu)\end{array}$ \\
\hline $\mathrm{C}_{3} \mathrm{~S}$ & 3.0 & $1450 \sim 1500$ & 23 & $\operatorname{grain}(3)$ & 1.0 \\
\hline$\beta-\mathrm{C}_{2} \mathrm{~S}$ & $2.0^{\circ}$ & $1450 \sim 1500$ & 15 & irreg. cryst. (3) & B) 1.0 \\
\hline
\end{tabular}

- added less than $1 \%$ of $\mathrm{Cr}_{2} \mathrm{O}_{3}$

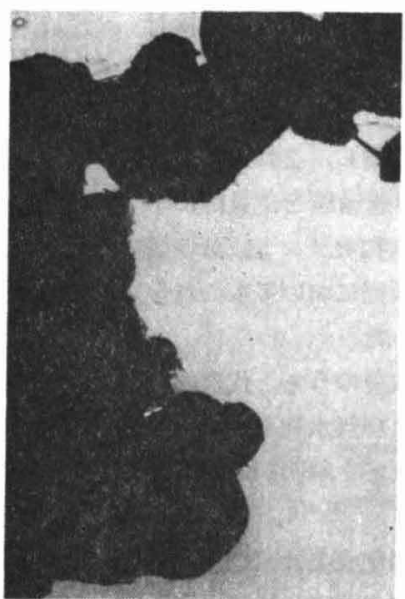

1) $\mathrm{C}_{3} \mathrm{~S}(\times 3,800)$

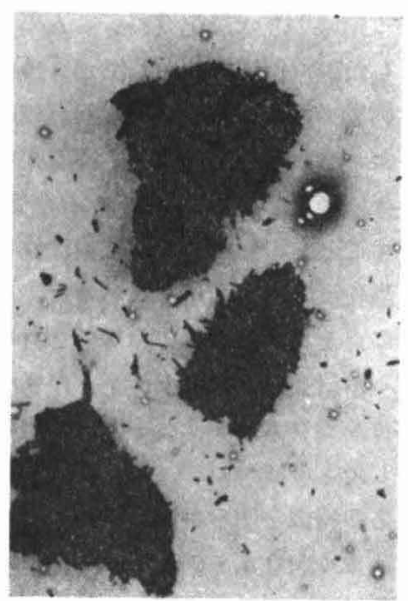

2) $\beta-C_{2} S(\times 3,800)$
Fig. 2. Electron micrograph of anhydrous calcium silicate samples. 
た試料に $100 \% \mathrm{CO}_{2}$ ガス（湿度 $100 \%$ ）を反応させた。 温度は $20^{\circ} \mathrm{C}$.

2.3 反応率 および 結晶質炭酸カルシウム（カルサイ

\section{卜) 生成率}

試料残留量㧍よびカルサイト生成量はX線回折（粉末 法）による定量を行ない，定時閒法で測定した。使用す る回折線の種類 $\left(2 \theta\left(\mathrm{Cu} \mathrm{K}_{\alpha}\right)\left(^{\circ}\right)\right)$ はゾノトライト 32.8 , トベルモライト (1) 30.4 ，トベルモライト (2) 7.6 , カ ルサイト 48.4, $\mathrm{MgO}$ (内部標準物質) 62.3 である. 装置は理学電機 (株) の自記X線回折装置（ガイガーフ レックス D-1 型) である.

反応率核試料の残留量から反応した量を求め, 初めの

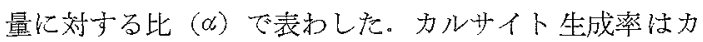
ルサイト量を相当する試料量に換算し，初めの試料量に 対する比で表わした，反応率とカルサイト生成率の差は 非晶質炭酸カルシウムの生成率孛示寸。

\section{4 炭酸化生成物の検討}

結晶質生成物はX線回折により同定した. 非晶質生成 物は赤外線吸収スペクトル $(\mathrm{KBr}$ 錠剤法)の結果から 検討した。装置は日本分光工業 (株) 赤外線自記分光光 度計 (IR-S 型) で岕る。

\section{5 反応速度式および速度の表示方法}

前報》で提案した反応速度式および速度の表示方法を
本研究においても用いる. 速度式は次の通りである:

$$
\left[r_{0}\left\{1-(1-\alpha)^{1 / m}\right\}\right]^{n+1}=(n+1) \bar{K} t
$$

ここで, $r_{0}$ : はじめの粒子半径 $[\mu], \alpha$ : 反応率， $m$ : 試料の形状定数, $n$ : 律速過程索示寸定数, $t$ : 反応時間 $[\mathrm{hr}], \bar{K}$ : 速度定数 $\left[\mu^{n+1} / \mathrm{hr}\right]$.

律速過程は $n$ 值により次のように与えられる.すなわ ち, $n=0$ は表面反応律速, $n=1$ は定常の反応層桩散律 速, $n>1$ は非定常の反应層散律速である.

前辫でのべたよらに，この式を実験結果に適用して得 られる定数 $n$ 抢よび速度定数 $\bar{K}$ の值の大小注反忘の進 行の遅速を予測させるので，各反応につきこれらの值を 求め反応速度の表示とした. その5ち $n$ 值は律速過程を 定量的に示すもので, 反応の進行は主としてこの值にも とづいて論じた。

なお本実験の試料の $m$ 值は, その形状から, ゾノト ライトでは 2 ，トベルモライトでは $1, \mathrm{C}_{3} \mathrm{~S}$ および $\beta$ $\mathrm{C}_{2} \mathrm{~S}$ では 3 とする。

\section{3. 実 験 結 果}

\section{1 反応率とカルサイト生成率}

ゾノトライトの炭酸化反応をガス反応および液反応で 行なった場合，反応率およびカル少住生成率と反応時 間の関係は 図-3の上らになる。 また反応の律速過程を
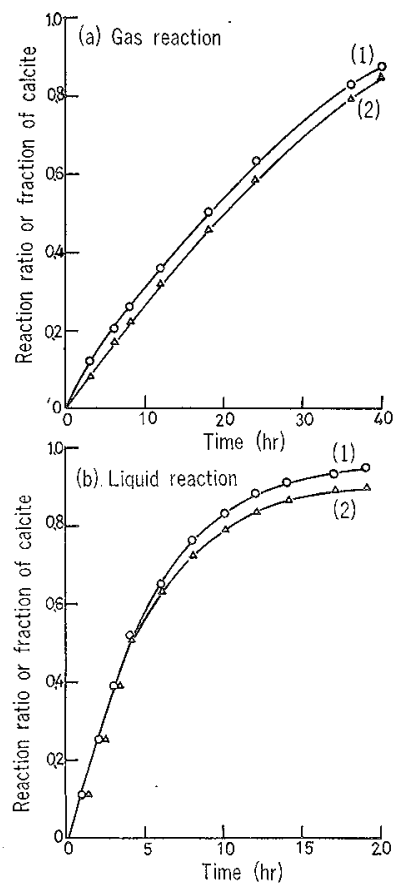

Fig. 3. Reaction ratio $(\alpha)$ vs. reaction time $(t)(1)$ and fraction of calcite in $\mathrm{CaCO}_{3}$ vs. reaction time (2) in the carbonation of xonotlite.
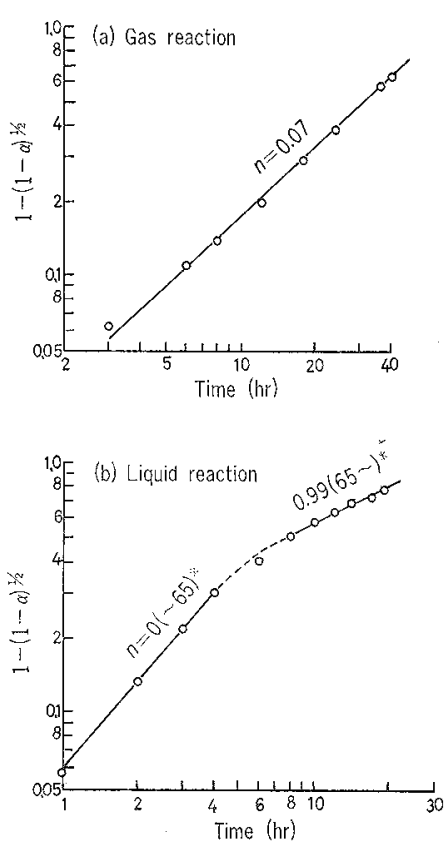

* Range of reaction ratio (\%) applied for $n$

Fig. 4. $1-(1-\alpha)^{1 / 2}$ vs. $t$ in the carbonation of xonotlite as shown in Fig. 3.

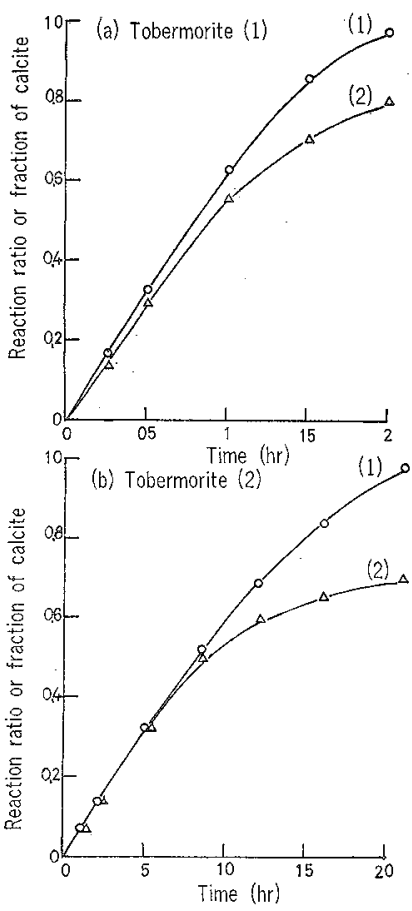

Fig. 5. Reaction ratio vs, reaction time (1) and fraction of calcite in $\mathrm{CaCO}_{3}$ vs. reaction time (2) in the carbonation of tobermorites. 
示す $1-(1-\infty)^{1 / 2}$ と $t$ の関係は 図-4.の通りである。その結果, ガス反応では, 速度式 (1)のn 值は 0.07 で，反応層の搪散抵抗 は小さく表面反応律速で苏る。液 反応では, 反忘率約 $65 \%$ まで $n$. 值は 0 で表面反忘律速, 以後の $n$ 值は 0.99 で定常の反店層拡散が 律速する。

ゾノトライトの反応で生成する 炭酸カルシウムは，図-3 (a) に みるように主として結晶質（カル サイト）であって，非晶質は少な い。また液反応はガス反応に比へ， 初期に扣いて結晶質が多い。

トベルモライト (1) およびト ベルモライト (2) のガス反忘の 場合, 反忘摔挍よびカルサイト生 成率と反応時間の関係は 図-5の 通りである。また律速過程は $\alpha$ と $t$ の関係で示され。図-6 のよう になる・トベルモライト (1) およ びトベルモライト（2）の反応で は $n$ 值はともに 0 で，表面反応律 速を示す。しかし、トベルモライト（1）はトベルモライ ト（2）に比心，速度定数 $\bar{K}$ の值恔大きく，表面反忘 が速い。

図-5（a）に示すようにトベルモライトの反応でも炭
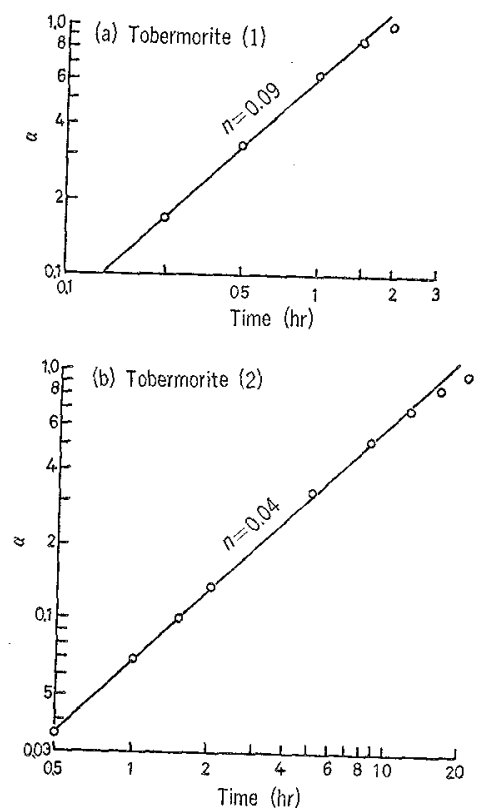

Fig. 6. $\alpha$ vs. $t$ in the carbonation of tobermorite (1) and (2) as shown in Fig. 5.

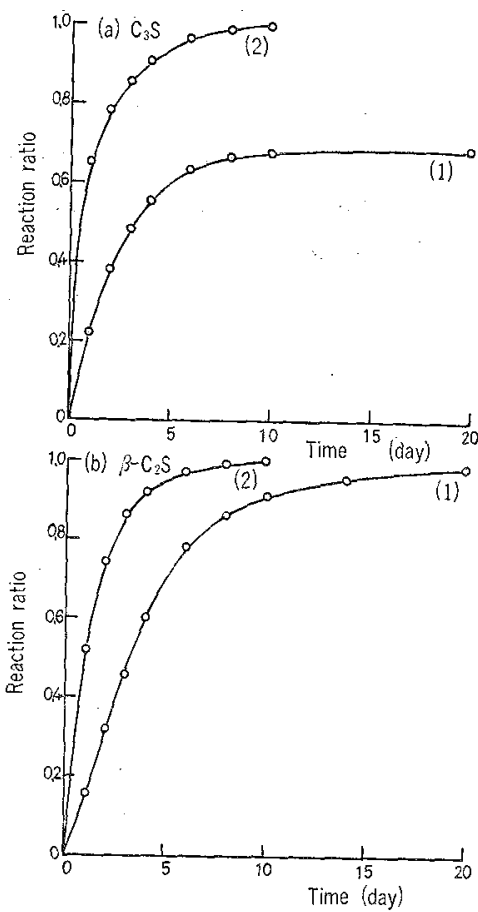

Fig. 7. Reaction ratio vs. reaction time in the gas reaction 1 ) and in the liquid reaction 2) for carbonation of $\mathrm{C}_{3} \mathrm{~S}$ and $\beta-\mathrm{C}_{2} \mathrm{~S}$.
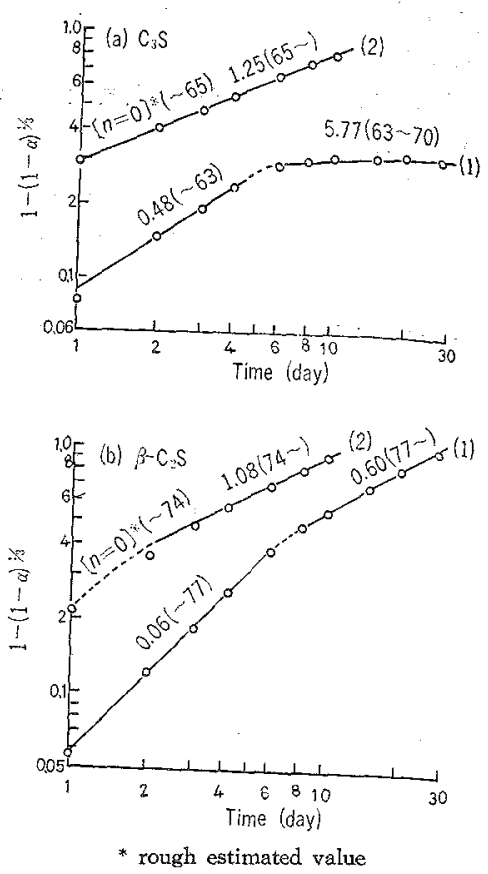

Fig. $81-(1-\alpha)^{1 / 2}$ vs. $t$ in the gas reaction (1) and in the liquid reaction (2) for carbonation of $\mathrm{C}_{3} \mathrm{~S}$ and $\beta-\mathrm{C}_{2} \mathrm{~S}$ as shown in Fig. 7.

酸カルシウム注結晶質（カルサイト）を主とするが，ジ ノトライトに比べ，やや非晶質が多い，またトベルモラ イト（1）はトベルモライト（2）に比べ，初期に掠いて 非晶質吕多い。

$\mathrm{C}_{3} \mathrm{~S}$ 拉よび $\beta-\mathrm{C}_{2} \mathrm{~S}$ についてガス反応拉よび液反忘を 行なった結果，反応率の時閒的経過注 図-7 の通りであ る. また $1-(1-\alpha)^{1 / 3}$ と $t$ の関係は 図-8 のようとな る. $\mathrm{C}_{3} \mathrm{~S}$ のガス反応では，反応率約 $63 \%$ まで $n$ 值は 0.48 ，その後は 5.77 となる。液反応は 反応率約 $65 \%$ まで 0 ，その後は 1.25 となる。 $\beta-\mathrm{C}_{2} \mathrm{~S}$ の ガス反応で は, 反応摔約 $77 \%$ 东で $n$ 值は 0.06 , その後は 0.60 と なる。液反応は反応率約 $74 \%$ まで 0 ，その後は 1.08 となる。その結果， $\mathrm{C}_{3} \mathrm{~S}$ および $\beta-\mathrm{C}_{2} \mathrm{~S}$ の反忘は水和物 の反忘に比へると和そいが，加なり速く進むこと， $\beta$ 一 $\mathrm{C}_{2} \mathrm{~S}$ の反忘は一般に $\mathrm{C}_{3} \mathrm{~S}$ 上り速いこと，お上び液反灾 はガス反応に比べ速いことがわかる，关の反応進行につ いては $n$ 値の示亦律速過程から説明できる.

\section{$3.2 \mathrm{X}$ 線回折}

炭酸化試料中の結晶質生成物を $\mathrm{X}$ 線回折に上り同定し た、ゾノトライト，トベルモライト（1）抢よびトベル モライト（2）の原試料とそのガス反忘就よび液反応試 料の代表的な X線回折図は 図-9 の通りである。その結 果，いずれも炭酸化試料中の結香質生成物は炭酸カルシ ウムで，关の結晶型はカルサイトであって，一般に回折 
(a) Xonotlite

(1) Original

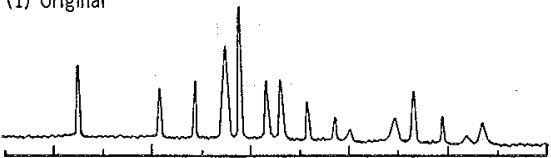

(2) Gas reaction (12hrs)
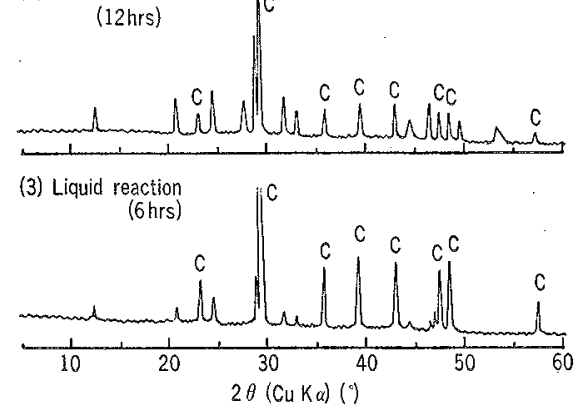

(b) Tobermolite (1)

(1) Original

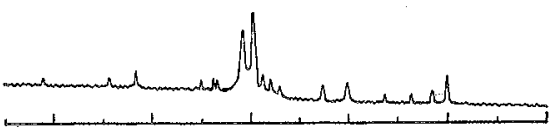

'(2) Gas reaction
(1 hrs)

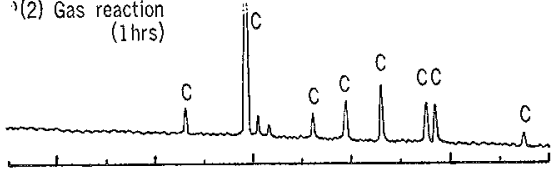

(3) Liquid reaction

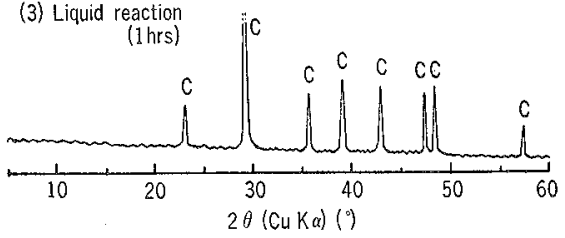

(c) Tobermorite (2)

(1) Original
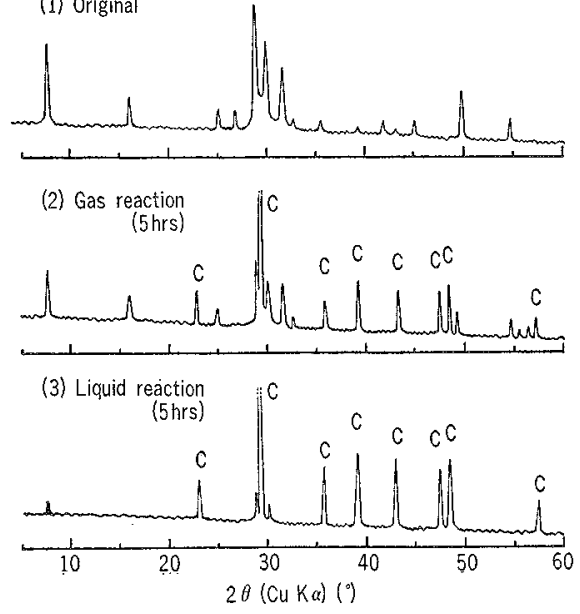

$\mathrm{C}:$ Calcite none : Original

Fig. 9. X-ray diffraction patterns of products in the carboration of hydrated calcium silicates. (a) $\mathrm{C}_{3} \mathrm{~S}$

(1) Original
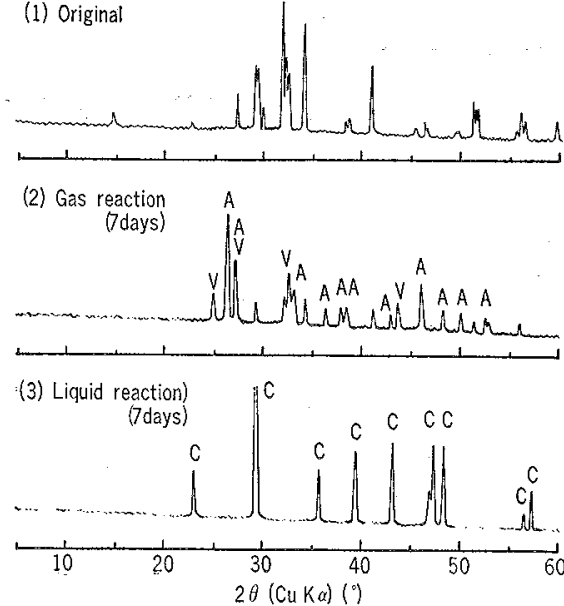

(b) $\beta-C_{2} S$

(1) Original
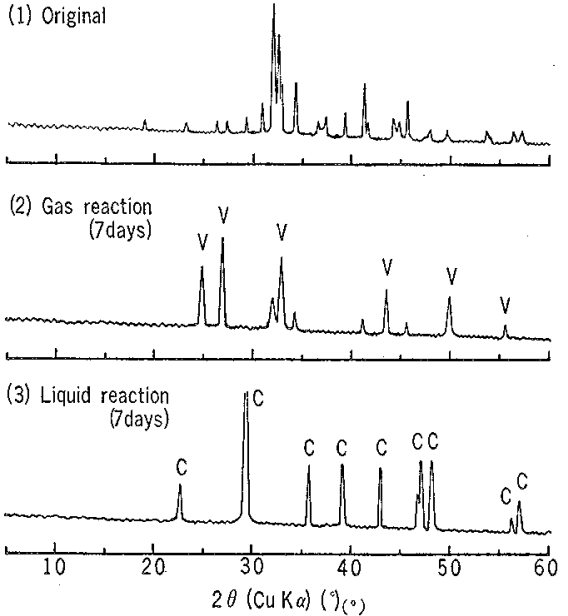

$\mathrm{A}:$ Aragonite $\mathrm{V}$ : Vaterite $\mathrm{C}:$ Calcite none : Original

Fig. 10. X-ray diffraction patterns of products in the carbonotion of anhydrous calcium silicates.

線の強度が強く生成量が多いことを示している。また液 反応はガス反応に比べて結晶質の生成量が多い傾向にあ る.

$\mathrm{C}_{3} \mathrm{~S}$ 拉よび $\beta-\mathrm{C}_{2} \mathrm{~S}$ の原試料と，それぞれのガス反応 招上び液反応試料の代表的な X 線回折図は 図-10 の通 りである。その結果， $\mathrm{C}_{3} \mathrm{~S}$ および $\beta-\mathrm{C}_{2} \mathrm{~S}$ の炭酸化では 水和物の反応に比心，結晶質炭酸カルシウムの生成量が 少なく，多量の非晶質を生じていることがわかる。また 結晶質はガス反応の場合， $\mathrm{C}_{3} \mathrm{~S}$ から多量のアラゴナイ 卜と少量のバテライトを生じるが， $\beta-\mathrm{C}_{2} \mathrm{~S}$ からはバテ ライトのみを生じる。これらは 28 日の反悥でもカルサ イトを生成しない。液反応の場合はいずれもカルサイト だけとなる。

3.3 赤外線吸収 $(\mathbb{I R})$ スペクトル 


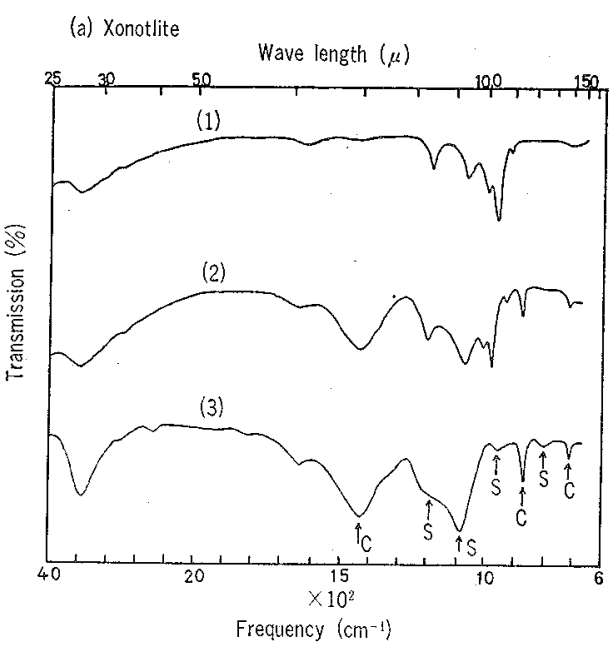

(1) Original (2) Gas reaction (1 day) (3) Liquid reaction (3 day) (b) Tobermorite (1) Wave length" ${ }^{3}(\mu)$

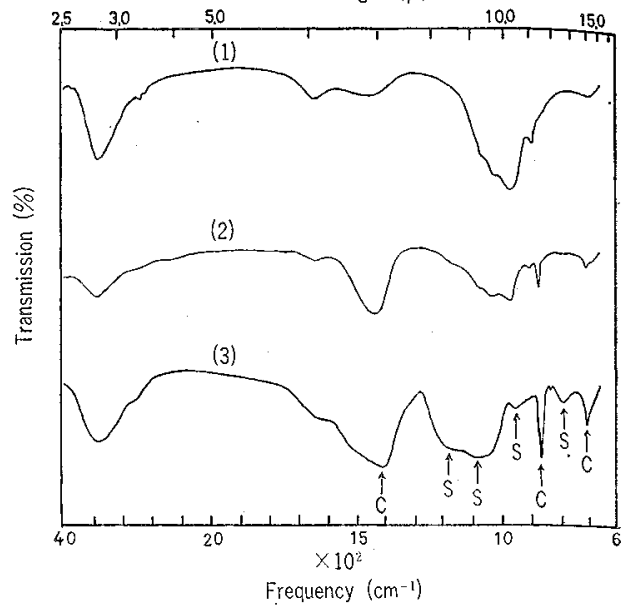

(1) Original (2) Gas reaction $(0.5 \mathrm{hr})$

(3) Liquid reaction $(5 \mathrm{hr})$

$\mathrm{S}:$ Hydrated $\mathrm{SiO}_{2}$ gel $\mathrm{C}: \mathrm{CaCO}_{3}$

Fig. 11. Infrared absorption spectra of products in the carbonation of hydrated calcium silicates.

X線回折で明らかにできない非晶翼生成物について， IR スペクトル測定結果から検討した。

ゾノトライト拉よびトベルモライトの原試料を，その ガス反応拉よび液反応試料の 代表的な IR スペクトル 図は 図-11 の通りである。ゾノトライトのガス反忘試 料の $715,875,1,430 \mathrm{~cm}^{-1}$ の吸収は カルサイトの吸収 にほぼ一致するので, 非晶質の炭酸カルシウムの生成は 少ない。また $795,955,1,085,1,180 \mathrm{~cm}^{-1}$ の吸収はシ リカ・ゲルの吸収 ${ }^{7)}$ に相当するので，非晶質の水和珪酸 を生成していることが確かである。液反応試料ではい。

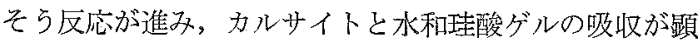
著となっている。

トベルモライト（1）のガス反応試料では，炭酸カル シウムに相当する吸収はカルサイトにほぼ一致するが， $1,430 \mathrm{~cm}^{-1}$ 附近の吸収はかなりブロードになることか ら非晶質の生成が推定される。また水和珪酸バルの吸収 がゾノトライトの反応と同様に認められる，液反応で は，前記の非晶質炭酸カルシウムの吸収は生じないで, カルサイトの吸収を示している。

\section{4. 考察}

\section{1 カルシウム・シリケート水和物の崖酸化反応}

4.1 反応速度 カルシウム・シリケート水和物 の炭酸化反応恃，化合物中の $\mathrm{Ca}^{2+}$ イオンと珪酸基の結 合が $\mathrm{CO}_{2}$ ガスの作用により切断され，炭酸カルシウム と水和珪酸を生じる反応で，その反応式を簡略に示すと 次の上うになる。

$$
\begin{array}{r}
x \mathrm{CaO} \cdot \mathrm{SiO}_{2} \cdot y \mathrm{H}_{2} \mathrm{O}+x \mathrm{CO}_{2}+z \mathrm{H}_{2} \mathrm{O} \\
=x \mathrm{CaCO}_{3}+\mathrm{SiO}_{2} \cdot\left(y^{\prime}+z^{\prime}\right) \mathrm{H}_{2} \mathrm{O}
\end{array}
$$

$$
+\left(y^{\prime \prime}+z^{\prime \prime}\right) \mathrm{H}_{2} \mathrm{O}
$$

反応形式は共存する水分量に左右され，水分が少ない 場合は水分の触媒作用により水和物と $\mathrm{CO}_{2}$ ガスの反応 が起り。水分が多い場合は $\mathrm{CO}_{2}$ ガスは炭酸 $\left(\mathrm{H}_{2} \mathrm{CO}_{3}\right)$ となって反応寸るすのと思われる。

反応の進行は Jander タイプの速度式が適用され, 生 ビた反応層の性質が重要に関係し律速過程を決定する. すなわち，反応層中の $\mathrm{CO}_{2}$ 拡散の抵抗が小さい場合は 主として表面反応律速となるが，抵抗が大きい場合は反 応層搪散の過程が律速する.

反応生成物は反応条件によって影響され，炭酸カルシ ウムの結晶化度や結晶の種類，水和珪酸の結合水量や結 晶性を異にする。この反応生成物の性状は反応層の性質 を決定する重要な要素と思われる。

実験結果から，ゾノトライト抒よびトベルモライトの ガス反応では，図-4 (a) および 図-6 (a), (b) に示し たように， $n$ 值からみて反応の全般を通じ表面反応律速 の過程をとり反応が速いことがわかる。すなわち，反応 層は常に porous で $\mathrm{CO}_{2}$ 拡散の抵抗が著しく小さい. このような反応層の性質は生成する炭酸カルシウムの性 状が密接に関係するものと思われる。図-3（a）抒よび 図-5 (a)，(b) の炭酸カルシウムの結晶化度の結果によ れば，いずれも炭酸カルシウム治始加ら結晶質（カル サイト）を主体とするが，また反応の進行にしたがい起 る非晶質の結晶化はほとんど進まない。したがって反応 層は porous な性質を持続すると考允られる.

一方ゾノトライトおよびトベルモライトの液反応で は，反応の進行はガス反応と異なり，始好速いが後に著 しくお括々なる。トベルモライトについては反応が速い 
Table 3. Rate constant $\bar{K}$ in the carbonation of calcium silicates.

\begin{tabular}{|c|c|c|c|c|c|c|c|c|c|}
\hline \multicolumn{5}{|c|}{ Gas reaction } & \multicolumn{5}{|c|}{ Liquid reaction } \\
\hline Species & State & $\begin{array}{l}\text { Conc. } \\
\text { of } \mathrm{CO}_{2} \\
(\%)\end{array}$ & $\begin{array}{l}\text { Temp. } \\
\left({ }^{\circ} \mathrm{C}\right)\end{array}$ & $\begin{array}{c}\bar{K} \text { (Range) }{ }^{*} \\
\left(\mu^{n+1} / \mathrm{hr}\right)(\%)\end{array}$ & Species & $\begin{array}{c}\text { Water } \\
\text { quantity } \\
(\%)\end{array}$ & $\begin{array}{l}\text { Conc. } \\
\text { of } \mathrm{CO}_{2} \\
(\%)\end{array}$ & $\begin{array}{l}\text { Temp. } \\
\left({ }^{\circ} \mathrm{C}\right)\end{array}$ & $\begin{array}{c}\bar{K} \text { (Range)* } \\
\left(\mu^{n+1} / \mathrm{hr}\right)(\%)\end{array}$ \\
\hline Xonotlite & Dry & 100 & 20 & $1.23 \times 10^{-3}$ & Xonotlite & 100 & 100 & 20 & $\left\{\begin{array}{l}5.80 \times 10^{-3}(<65) \\
1.70 \times 10^{-4}(>65)\end{array}\right.$ \\
\hline Tobermorite(1) & " & $"$ & $"$ & $4.48 \times 10^{-2}$ & Tobermorite(1) & $"$ & $"$ & 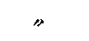 & - \\
\hline Tobermorite (2) & $"$ & $"$ & " & $5.52 \times 10^{-3}$ & Tobermorite(2) & $"$ & $"$ & " & - \\
\hline $\mathrm{C}_{3} \mathrm{~S}$ & $"$ & $"$ & $"$ & $\left\{\begin{array}{l}7.46 \times 10^{-4}(<63) \\
2.07 \times 10^{-7}(>63)\end{array}\right.$ & $\mathrm{C}_{3} \mathrm{~S}$ & " & " & " & $\left\{\begin{array}{l}6.71 \times 10^{-3}(<65) \\
1.14 \times 10^{-3}(>65)\end{array}\right.$ \\
\hline$\beta-\mathrm{C}_{2} \mathrm{~S}$ & $"$ & $"$ & $"$ & $\left\{\begin{array}{l}1.85 \times 10^{-3}(<77) \\
9.95 \times 10^{-4}(>77)\end{array}\right.$ & $\beta-\mathrm{C}_{2} \mathrm{~S}$ & $"$ & $\Rightarrow$ & $"$ & $\left\{\begin{array}{l}6.41 \times 10^{-3}(<74) \\
1.53 \times 10^{-3}(>74)\end{array}\right.$ \\
\hline
\end{tabular}

* Range of reaction ratio (\%) applied for $\bar{k}$

ため定量的な結果は得られなかったが，ゾノトライトの 反応は 図-4 (b) にみる通り，始为表面反応律速で進む が，途中より定常の反応層拡散律速となる。始めの速い 反応は 表 -3 の速度定数 $\bar{K}$ の值からみて, ガス反応よ りも反応が容易に起るものと思われるが，詳細について 検討していない。後の搪散律速の過程怯 図-3(b) の結 果から, 液反応では非晶質の再溶解をともなら炭酸カル シウムの結晶化が進み，反応層の拡散抵抗を増寸ため生 ビるものと思われる．液反応に和ける同様な律速過程の 変化は前報1) の水酸化カルシウムの炭酸化反応飞抒いて もみられた。な㧍ガス反応および液反応における炭酸カ ルシウムの形態とその生成条件について，同樣な結果を $\mathrm{Nicke}^{8)}$ および Towe $\mathrm{e}^{8)}$ により報告されている。

4.1 .2 ゾノトライトと $11 \AA$ トベルモライトの反応 性の比較 ゾノトライトと $11 \AA$ ト ドルモライトのガ ス反応は，前述したようにともに表面反応律 速で亦る が，その反応の速さには明らかに差がみられる，固体反 応速度式の式 (1) によれば, 速度定数 $\bar{K}$ の值は一般 に反応層拡散の容易さを表わすが，表面反応律速の場合 は表面反応の容易さ，すなわち化合物の反応性を表わす と考えることができる．表-3 の速度定数 $\bar{K}$ の值はジ ノトライトの方が $11 \AA$ トベルモライトより小さく, そ の反応性は小であると推察される。

前述したように炭酸化に掠いては，化合物中の $\mathrm{Ca}^{2+}$ イオンと珪酸基の結合が $\mathrm{CO}_{2}$ ガスの作用により切断さ れるので，その結合の強さは反応性に密接に関係するも
のと思われるが，現在のセメント化学はこの結合の強さ について適切な説明を与えていない。

ゾノトライトおよび $11 \AA$ トベルモライトは水熱法 により合成されるが，その生成条件は異なり，ゾノト イトが 飽和水蒸気圧下の $150^{\circ} \sim 400^{\circ} \mathrm{C}$ の範囲で生成す るのに対し，11 ̊ トベルモライトはそれより低い $110^{\circ}$ $\sim 140^{\circ} \mathrm{C}$ に扔いて生成する ${ }^{2)}$. その結果, 表 -4 の単位格 子や密度からわかるように, ゾノトライトは $11 \AA$ トベ ルモライトよりも緻密な構造をとり，そのため反応性が 小さいと考㝋られる。

4.1.3 トバルモライトの結晶性と反応、ベルモ ライトは構造の似た種々の化合物があり，結晶性によっ て結晶質, 半結晶質 (semicrystalline) おょび非晶質に 分類されている 酸化反応の関係を検討した際, 水和生成物のトベルモラ イトの反応はその結晶性によって著しく異なることを知 った ${ }^{10)}$. 本研究では結晶性の異なる 2 種のトベルモライ 卜の炭酸化反応を検討して扔り，その結果から結晶性の 相違が反応に㧍よぼす影響を考察する。用いた試料はX 線回折によると，トベルモライト (1) は C-S-H (I) に近い半結晶質, トベルモライト (2) は $11 \AA$ トベル モライトに近い結晶質である。

図-6に示した 2 種のトベルモライトのガス反応は, いずれも表面反応律速であるが，反応はトベルモライト

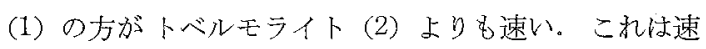
度定数 $\bar{K} の$ 值加みて, 雨者の反応性に差があるため

Table 4. Crystallographic data of calcium silicate compounds ${ }^{2)}$.

\begin{tabular}{|c|c|c|c|c|c|}
\hline Compound & $\begin{array}{l}\text { Tricalcium } \\
\text { silicate } \\
\left(\mathrm{Ca}_{3} \mathrm{SiO}_{5}\right)\end{array}$ & $\begin{array}{l}\beta-\text { Dicalcium } \\
\text { silicate } \\
\left(\beta-\mathrm{Ca}_{2} \mathrm{SiO}_{4}\right)\end{array}$ & $\begin{array}{c}\text { Xonotlite } \\
\left(\mathrm{Ca}_{6} \mathrm{Si}_{6} \mathrm{O}_{17}(\mathrm{OH})_{2}\right)\end{array}$ & $\begin{array}{c}11 \AA \text { Tobermorite } \\
\left(\mathrm{Ca}_{5}\left(\mathrm{Si}_{6} \mathrm{O}_{18} \mathrm{H}_{2}\right) \cdot 4 \mathrm{H}_{2} \mathrm{O}\right)\end{array}$ & $\begin{array}{c}\mathrm{C}-\mathrm{S}-\mathrm{H}(\mathrm{I}) \\
\left(0.8-1.5 \mathrm{CaO} \cdot \mathrm{SiO}_{2} \cdot 0.5-2.5 \mathrm{H}_{2} \mathrm{O}\right)\end{array}$ \\
\hline \multirow{6}{*}{ Unit cell } & triclinic & monoclinic & orthorhombic & orthorhombic & orthorhombic \\
\hline & $a=12.915 \AA$ & $a=5.514 \AA$ & $a=17.10 \AA$ & $a=11.24 \AA$ & $a=11.2 \AA$ \\
\hline & $b=7,104 \AA$ & $b=6.757 \AA$ & $b=7.34 \AA$ & $b=7.30 \AA$ & $b=7.3 \AA$ \\
\hline & $\begin{array}{l}c=25.096 \AA \\
\alpha=90^{\circ}\end{array}$ & $c=11.197 \AA$ & $c=14.06 \AA$ & $c=22.6 \AA$ & $c=9 \sim 14 \AA$ \\
\hline & $\beta=89.8^{\circ}$ & $\beta=123.98^{\circ}$ & & & \\
\hline & $r=89.8^{\circ}$ & & & & \\
\hline$Z$ & 18 & 4 & 4 & 4 & $10 \mathrm{Ca}$ \\
\hline$D$ & $3.12 \sim 3.25$ & 3.28 & 2.7 & $2.42 \sim 2.46$ & $2.0 \sim 2.2$ \\
\hline
\end{tabular}

$Z$ : number of units of formular in the cell 
と思われる。表-4 の単位格子や密度の值から, 半結晶 質は結晶質に比べ構造が不整になっているため, 反忘性 にとむと考光られる。また図-5 亿名通り，生成する 炭酸カルシウム忙トベルモライト (1) の方に非晶質が 多いことも速い反応によるものと思われる。

非晶質トベルモライトは常温養生のポルトランド・セ メント養生物中に多量生成する。本研究ではその反応に ついて直接検討していないが，これまでの実験結果 ${ }^{10)}$ 加ら, 非晶質は半結晶質よりもさらに反応性にとみ, 炭 酸化が速いことは明らかである。

\section{2 カルシウム・シリケート無水物の炭酸化反応}

\subsection{1 反応速度 ポルトランド・セメントに含まれ} る $\mathrm{C}_{3} \mathrm{~S}$ 扰よび $\beta-\mathrm{C}_{2} \mathrm{~S}$ は，通常不純物を混入して固溶 体を形成しており，その条件によって結晶の性状を異に する゙ 。したがって $\mathrm{C}_{3} \mathrm{~S}$ および $\beta-\mathrm{C}_{2} \mathrm{~S}$ の炭酸化反応の 進行は，その生成条件によって相違することが予想され る。本研究では純薬合成した $\mathrm{C}_{3} \mathrm{~S}$ および $\beta-\mathrm{C}_{2} \mathrm{~S}$ の各 一種のみにつき炭酸化反応を検討したが，各化合物の反

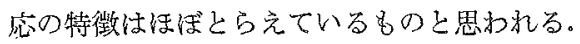

$\mathrm{C}_{3} \mathrm{~S}$ 抢よび $\beta-\mathrm{C}_{2} \mathrm{~S}$ の炭酸化反応にも, 前述した化学 反応式の式 (2) を与えることができる。その反応の進 行は固体反忘速度式の式（1）にしたがい，生成する反 応層の性質によって律速過程が決定される。

実験結果によ礼ば， $\mathrm{C}_{3} \mathrm{~S}$ のガス反応では 図-8 (a) に 示す上うに, 反応は始め表面反忘律速であるが, 反応が 進むとともに反応層の $\mathrm{CO}_{2}$ 拡散の抵抗を増し, 途中で 反応層拡散律速に变わる。また拡散の比抵抗一一単位体 積当りの抵抗一一変化にともない, 拡散過程は定常拡 散加非定常拡散に変わり，反応の進行は著しくおそく なる.この反応層の性質は前述した水和物の反応と同 㥞, 炭酸カルシウムの性状々密接な関係があると思われ る。すなわち，図-10 (a) にみるょうに $\mathrm{C}_{3} \mathrm{~S}$ のガス反 応では, 生成する炭酸カルシウムは始如非晶質を主とす るが，後に結晶質のアラゴナイトに変化して捛り，反応 層の性質も次第に変わると考えられる。

一方, 図-8 (a) に示した $\mathrm{C}_{3} \mathrm{~S}$ の液反忘では, ガス反 応に比べ表面反応律速の過程が長く, また拡散律速過程 の抵抗の増加が少ないため, 反応の進行が速い。炭酸カ ルシウムは 図-10 (a) に多る通り結晶質が多く，その 結晶型はカルサイトであって，反忘層の性質は水和物の 液反応の場合と似ているため反忘の進行は速いと考えら れる。

$\beta-\mathrm{C}_{2} \mathrm{~S}$ の反応についても, 図-8 (b) に示すガス反応 扔よび液反応に挍いて， $C_{3} \mathrm{~S}$ と同様の反応経過をたど り，表面反店律速とそれ続く反応層拡散律速の過程を とることがわかる。

しかし $\beta-\mathrm{C}_{2} \mathrm{~S}$ の反応は明らかに $\mathrm{C}_{3} \mathrm{~S}$ に比べ進行が
速い。これは反応層の搪散抵抗の増加が比較的小さいた めと思われる。このような反忘層の成因について次のよ らに教えるとができる。いま表-4の $\mathrm{C}_{3} \mathrm{~S}$ の密度 3.18 および $\beta-C_{2} \mathrm{~S} 3.28$ を用い, 反応にともなら容積 変化がないとして。結合する $\mathrm{CO}_{2}$ 量に相当する重量增 加を考慮したものを反危層の密度とすると， $\mathrm{C}_{3} \mathrm{~S}$ では $5.03, \beta-\mathrm{C}_{2} \mathrm{~S}$ では 4.95 となる。炭酸カルシウムや水 和珄酸ゲルの生成による容積増加が若干あるとしても， 反店層の緱密さの增加は $\beta-\mathrm{C}_{2} \mathrm{~S}$ の方が小さいと思わ れ，その拡散抵抗の増加も小さい。このことはまた 図一 10 (a)，(b) の結果加ら，生成する結晶質炭酸カルシウ 厶が $\mathrm{C}_{3} \mathrm{~S}$ では密度の大きいアラゴナイト $(D=2.93)$ であるのに対し， $\beta-\mathrm{C}_{2} \mathrm{~S}$ では密度の小さいバテライト $(D=2.65)$ を生じる事赛仙よっても明らかであるう。

\section{$4.2 .2 \quad \mathbb{C}_{3} \mathrm{~S} \& \beta-\mathbb{C}_{2} \mathrm{~S}$ の反応性の比較炭酸化に} 扮讨る $\mathrm{C}_{3} \mathrm{~S}$ 抒よび $\beta-\mathrm{C}_{2} \mathrm{~S}$ の反応性 は, 各反忘の表面 反応律速の過程について求めた速度定数 $\bar{K}$ の值 (表-3) から推測されるが，その結果反忘は $\beta-\mathrm{C}_{2} \mathrm{~S}$ の方が $\mathrm{C}_{3} \mathrm{~S}$ よりやや大であるがあまり差はない。

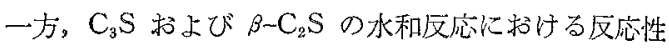

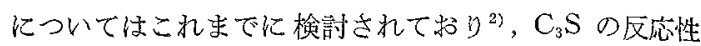
は $\beta-\mathrm{C}_{2} \mathrm{~S}$ に比べると著しく大きいことが知られている。

このように $\mathrm{C}_{3} \mathrm{~S}$ \& $\beta-\mathrm{C}_{2} \mathrm{~S}$ の反応性吕 炭酸化と水和 に抢いて相違する事実は，炭酸化機構を解明するらえに 重要な手掛りを与えるものと思われる。炭酸化時の $\mathrm{CO}_{2}$ ガスの反応は共存水分により促進されるが，無水物の反 応に招行るこの水分の作用機構学考察するを次の上うに なる。もし水分がまず無水物に作用して水和物を生し， これに $\mathrm{CO}_{2}$ ガスが反応するものとすれば，水和物の炭 酸化は前述したように速い反応であるから，水和反忘が この場合の律速過程になる。したがって炭酸化の反応性 は水和の反応性と似たものになるはずであるが，事実は これに反している。すなるち水分の作用は上記と異な り，水和物の反応に抒けるむのと同㥞で西ると考えるこ とができる．同じ結論は後報11でのべるカルシウム・ア ルミネート無水物の炭酸化反応に括いても得られてい る。

\section{5. 総括}

本研究では水和セメントの構成成分のうち，代表的な カルシウム・シリケート水和物掠よび無水物について, 個々に炭酸化反応を検討乙，その反応の特徴を明らかに した。炭酸化の方法法ガス反応拉よび液反応を用い，各 反応に速度式を適用して律速過程を明らかにし，また反 応生成物の種類，性状を検討した。得られた結論は次の 通りである。

カルシウム・シリケート水和物の反忘は一般に反応の 
15 浅野睖吉ほか

進行が速く，反応層の性質からみて，主として表面反応 が律速することがわかる。高温生成型のゾノトライトと 低温生成型のトベルモライト, 結晶性の異なるトベルモ ライトの間に反応性の相違がみらられ，反応の進行を異に する。店应成物は炭酸カルシウムと水和珄酸ゲルであ る。炭酸カルシウムは水和物の反応では結晶質を主とす ることが特徴で, その結晶型はガス反応, 液反応ともカ ルサイトである。

カルシウム・シリケート無水物の反応は水和物に比べ ると進行が著しく肪そいが，カルシウム・アルミネート 無水物よりかなり速い。その律速過程は反応層の性質の 変化にともない反店層搪散が主体となる。 $\mathrm{C}_{3} \mathrm{~S}$ と $\beta-\mathrm{C}_{2} \mathrm{~S}$ の反応性は水和比沶いて著しく異なるが，炭酸化に扔い ては业まり差がない。この事実は炭酸化反応の機構解明 に重要な意義をもつものと思われる。無水物の反応で は, 生成する炭酸カルシウムは非晶質が多いのが特徴 で，この非晶質の結晶化による反店層の性質の変化が律 速過程に影響するものと思われる。結晶質はガス反応の 場合, $\mathrm{C}_{3} \mathrm{~S}$ ではアラゴナイト, $\beta-\mathrm{C}_{2} \mathrm{~S}$ ではバテライト を生じるが，液反応ではともにカルサイトを生じる。
箘業協会誌 79[9]1971 311

謝 辞 本研究を行なうに当り, 試料を提供され, 尔種々御 教示它賜った八幡化学工業 (株) の関係各位に対し深く感謝し 安す。

\section{文献}

1）浅野駿吉, 杉田達三, 山際康暎, 井上嘉笔, 寗協 79 [3] 14-23 (1971).

2) H.F.W. Taylor, "The Chemistry of Cement, Vol. 1 and 2", Academic Press, London and New York (1964).

3）須藤儀一, 窝協 69 [11] 23-34 (1961).

4) Yu.M. Butt, O.N. Gracheva, L.N. Rashkovich, A. A. Maier, D.M. Kheiser, "Doklady Mezhvuz. Konf. po Izuchen. Avtoktavn. Materialov i ikh Primeneniyn v Stroitel'stve", Leningrad 1959, 97-102; CA 56 11202 (1962).

5) I.N. Rashkovich, Stroit, Materialy 8[6] 31-3 (1962); CA 5710783 (1962).

6) G.J. Verbeck, "Special Technical Publication No. 205, ASTM" (1958).

7) H.A. Benesi, A.C. Jones, Phys. Chem. 63 179(1959).

8) H.J. Nickel, H.K. Henisch, J. Electrochem. 116 [9] 1258-60 (1969).

9) K.W. Towe, P.G. Malone, Nature 226 348-9 (1970).

I0）井上嘉龟，浅野駿吉，“セメント技術年報 XX” 80 (1966).

11）浅野駿吉，篣協 投稿中。[1/11/1971 受付] 